\title{
Dietetics, Health Reform and Social Order: Vegetarianism as a Moral Physiology. The Example of Maximilian Bircher-Benner (1867-1939)
}

\author{
ELISABETH MEYER-RENSCHHAUSEN and ALBERT WIRZ*
}

Having virtually disappeared from the canons of medicine during the early modern period, dietetics returned in the early nineteenth century as part of a new nutritional physiology tied to scientific "animal production" and, generally, to a new, market-oriented agriculture. This medical advocacy of meat-eating ran up against a counter-movement of a simultaneously developing "alternative" dietetics, as we might call it today, which advocated "natural" vegetarian eating habits as a new path to health. When, around the turn of the century, the Swiss nutritionist and physician Maximilian Bircher-Benner emerged as a charismatic leader of a new, gentle healing and life-style movement on the strength of his raw-food diet therapies, he did so against the background of a naturalhealing and life-reform movement that was at that time already some seventy years old.

It was an era when industrially-processed flour, sugar, and spirits, as well as the increasing consumption of meat, were beginning to characterize modern society's eating habits. Industrialization, by creating the technical possibilities for moving previously unheard-of quantities of wheat from large-scale farming areas to huge cities, for the first time gave rise to bread-baking on an industrial scale around 1820. For that purpose, flour had to be made capable of being stored. This was achieved by milling off the vitamin and protein-rich germ and aleuron layer, with the consequence that the resulting white bread was much less nutritious than the old corn porridges and coarse-grain breads had been. ${ }^{1}$

The increasing cheapness of spirits was the result of new distilling processes which took hold after about 1830, and it brought on a new "alcohol plague". Starting in the 1850 s, the invention of the crown-cork for bottles made possible "Lager"-literally: "storable"- -beer, which, too, had to be correspondingly modified, in this case with an alcoholic content double that of the old top-fermenting beer. ${ }^{2}$

* Dr Elisabeth Meyer-Renschhausen, Bülowstr 74, D-10783 Berlin. Prof. Dr Albert Wirz, Institute of Asian and African Studies, Humboldt University, Unter den Linden 6, D-10099 Berlin.

Our sincere thanks to Phil Hill, Berlin, for his comments and translation.

1 Siegfried Giedion, Mechanisation takes command, Oxford University Press, 1948, pp. 103-17; Elisabeth Meyer-Renschhausen, 'The porridge debate-grain, nutrition and forgotten food preparation techniques', in Food and FoodwaysExploration in the History and Culture of Human Nourishment, 1991, 5 (1): 95-120; Jakob Tanner, 'Mahlzeit in der Fabrik. Ernährungswissenschaft, Industriearbeit und Volksernährung in der Schweiz 1890-1950', unpubl. postdoc. dissertation, Basel, 1993.

2 Elisabeth Meyer-Renschhausen, Weibliche Kultur und soziale Arbeit: Eine Geschichte der ersten Frauenbewegung am Beispiel Bremens, 1810-1827, Cologne and Vienne, Böhlau, 1989, pp. 179-83. 


\section{Elisabeth Meyer-Renschhausen and Albert Wirz}

When, during the Napoleonic Wars, the British blockade forced central Europeans to find a way to get their sugar from beet, local availability and a new sugar-refining method led to such a reduction in its price that what had recently been a luxury product was now available even to the poor. Workers under the time pressure of industrialization began to replace their old breakfast porridge with a cup of thin coffee-or chicory substitute coffee-and sugar. As the American anthropologist Sidney Mintz puts it, food was replaced by drugs. ${ }^{3}$ By 1879 , fully one-third of the recipes in a common American cookbook were for puddings and cakes; in Britain, too, sweet plum puddings came into vogue. $^{4}$

Even more far-reaching in its consequences was the tendency during the nineteenth century throughout much of society to eat ever larger amounts of meat. England, the first capitalist nation, had already produced a veritable cult of meat during the seventeenth and eighteenth centuries, which, by the end of the nineteenth, had swept up the propertied classes of all of western Europe and North America. ${ }^{5}$ Although the French Revolution did away with the royal court, it not only spared its luxury cuisine, but even generalized itby way of the restaurant, a new symbol of bourgeois power. ${ }^{6}$ Meals and dinner parties became exercises in what the American sociologist Thorstein Veblen would later dub "conspicuous consumption"-a sign of the aristocratization of the bourgeoisie. The central element of this consumption was a staggering quantity and variety of meat dishes. But even the modest prosperity of significant parts of the lower classes was enough to permit an increase in meat consumption, especially among men, and not only in such new meat-producing areas as North America. The modern mass conscription-based armies of the late nineteenth century, in particular, turned millions of farm-boys with traditional dietary habits into meat-eaters. ${ }^{7}$

Of course, for the urban-and increasingly, even for the rural-poor, these changes meant a diet with plenty of white bread, sugar, and beer or gin, but little or no meat. Hunger and malnutrition were the rule for large segments of society, as school physicians in both the USA and Germany were to ascertain among six-year-olds they found to be physically and mentally underdeveloped as the result of malnutrition. While the rich suffered from obesity, gout, tooth-decay, diabetes, and arthritis, large parts of the working class were threatened by dysentery, TB, cholera, and mental retardation. ${ }^{8}$

3 Sidney W Mintz, Sweetness and power: the place of sugar in modern history, 2nd ed., New York, Penguin, 1986, ch. 3 on consumption, and the end of ch. 4 on power.

4 Harvey Levenstein, Revolution at the table: the transformation of the American diet 1880-1930, New York and Oxford, Oxford University Press, 1988 , p. 6.

5 Nick Fiddes, Meat, a natural symbol, London and New York, Routledge, 1991.

6 Stephen Mennell, All manners of food: eating and taste in England and France from the Middle Ages to the present, Oxford, Basil Blackwell, 1985, pp. 134-65.
7 Elisabeth Meyer-Renschhausen,

'Zivilisationsgeschichte der EBkultur', in Gabriele Klein and Katharina Liebsch (eds), Zivilisierung des weiblichen Ichs, Frankfurt, Suhrkamp 1997, pp. 129-53.

8 Harvey Levenstein, The paradox of plenty: $a$ social history of eating in modern America, New York, Oxford University Press, 1993; see too the corresponding reports of the Medizinalkommission just before and after World War I, in the Staatsarchiv, Bremen, 3-M.1. and SLAB Trunksucht 3-T.5. 


\section{Dietetics, Health Reform and Social Order}

In short, as the rich ate themselves sick, they at the same time disencumbered themselves of the constraints of what E P Thompson has called the "moral economy" of traditional society, which required the lord to stand by the peasant in time of need-and even to share that need (the lord could not hoard corn while his subjects starved; only his last loaf might he deny them). ${ }^{9}$ In both instances, the new urban bourgeoisie subjectively perceived the exact opposite: in regard to their diet, they imagined, on the strength of discoveries concerning protein structures by such scientists as Justus von Liebig, that their prodigious meat consumption habits represented the epitome of a healthy diet; at the same time, they saw themselves as the very embodiment of the Age of Enlightenment, and hence of humane kindness-while ignoring the misery around them.

\section{The Counter-Movement: Lebensreform}

This attitude inevitably engendered a reaction. Enlightened citizens concerned with questions of social justice, including not only intellectuals, but also craftspeople and literate workers, responded with a counter-movement for a "moral physiology" for temperance, natural health and vegetarianism, linked to the emerging groups pressing for social reform.

Beginning during the 1820 s and 1830 s and continuing as part of the revolutions of 1848 , this drive for change grew rapidly during the second half of the nineteenth century. By the last decade of the century, it had developed into a real "mass movement", complete with numerous associations and magazines. ${ }^{10}$ It was in effect the first example of what we would today call the "new social movements"-a secular movement arising from within bourgeois society, parallel to, and sharing important points of contact with, the rising workers' movement of the era. In the United States and Great Britain, the temperance associations were its main early manifestation; in Germany and neighbouring countries, natural-health and vegetarian associations were also very prominent. ${ }^{11}$

None the less, it was in Britain that the first vegetarian societies were founded, in 1847; by that time, the "modern sensitivity" toward nature had been growing for some 300 years. Regard for the welfare of animals, originating in utilitarian concerns, had rapidly assumed a "humane" aspect as well. Not only horses and pets benefited; even the search for a method of gathering honey without wiping out the entire bee hive-the traditional practice-was reportedly motivated as much by concern for the insects as by economic considerations. ${ }^{12}$

9 E P Thompson, “"Die sittliche Ökonomie" der englischen Unterschichten im 18. Jahrhundert', (Moral economy in the English lower classes in the eighteenth century) in Detlev Puls (ed.),

Wahrnehmungsform und Protestverhalten, Frankfurt am Main, Suhrkamp,1979, pp. 13-88.

10 Gunnar Stollberg, 'Die Naturheilvereine im deutschen Kaiserreich', Archiv für Sozialgeschichte, 1988, 28: 267-86.

11 Cornelia Regin, Selbsthilfe und Gesundheitspolitik. Die Naturheilbewegung im Kaiserreich, 1889 bis 1914, Stuttgart, Franz Steiner,
1995; Eva Barlösius, Naturgemäße Lebensführung. Zur Geschichte der Lebensreform um die Jahrhundertwende, Frankfurt and New York, Campus, 1997, pp. 172-210.

12 Keith Thomas, Man and the natural world: $a$ history of the modern sensibility, Pantheon Books, 1983 (the lst ed. was entitled Man and the natural world: changing attitudes in England 1500-1800, London, Allen Lane, 1983), p. 190. I wish to thank Gert Gröning, Hochschule der Künste, Berlin, for referring me to this source (EM-R). 
But it was only now that the term "vegetarianism" was coined. The German term "Naturheilkunde"-literally, "the science of natural healing"- had appeared during the 1850s; during the latter part of the century, its adherents often termed themselves "vegetarianists", 13 while its medical practitioners began to use the designation "physiotherapist"; 14 their practice included, in addition to diet, the use of water, exercise and air-bath cures. The narrower use of the term physiotherapy in the twentieth century with reference to treatment through physical exercise is testimony to its origins in the natural-health movement.

We will use the term "Lebensreformer"- "life-reformers"- to refer to the entire interlinked network which included supporters of vegetarianism and a healthy diet, opponents of alcohol, and members of the natural healing movements, although the term Lebensreform did not come into use in Central Europe until the end of the nineteenth century, and, strictly speaking, referred only to the more radical critics of modern civilization of that period. The term is none the less justified in retrospect, as it adequately describes the common denominator of its various component parts; and the use of a German term is appropriate, since the life-reform movement and the natural-health subculture were nowhere as strongly organized as in the German Empire. Testimony to this are such English loan-words as "Kneipp-sandals" or "Rucksack", the latter an indispensible accoutrement of the "Wandervögel", who, too, were Lebensreformer. But the Swiss dialect word "Müsli", given to us by Bircher-Benner, is perhaps the best-known of all. ${ }^{15}$

Even if the name was coined after the 1848 Revolution, the German natural-health movement itself arose during the 1830s, and was pitted against the growing rationalism in the medical sciences. It was an era of vibrant self-confidence and assertion for the homoeopathic practitioners challenging the hegemonic claims of university medicine, which they denounced as "Schulmedizin" ("school-medicine"-a term used to this day by natural-health advocates); instead, they harked back to older healing traditions. ${ }^{16}$

The fact that it was not simplistically anti-rationalistic is demonstrated by its connections with the philosophical traditions of the Enlightenment of the previous century and with the critical thought inherent in it, particularly the back-to-nature views of JeanJacques Rousseau (1712-1778). In Germany, an eighteenth-century advocate of such ideas was Christoph Wilhelm Hufeland (1762-1836), the immensely popular personal physician of the Prussian Queen Louise (wife of Frederick William III) and a friend of Goethe. His 1792 essay Makrobiotik oder die Kunst, das menschliche Leben zu verlängern

13 From Alfred Brauchle, Zur Geschichte der Physiotherapie. Naturheilkunde in ärztlichen Lebensbildern, ed. Walter Groh, Heidelberg, K F Haug, 1971, pp. 24-31 (shortened 4th ed. of Naturheilkunde in Lebensbildern, Leipzig, P Reclam jun., 1937).

14 Rolf Schwendter, 'Nahrungsmittel and Naturheilkunde im Kontext sozialer Innovationen', Österreichische Zeitschrift für Volkskunde, 1986, 89: 227ff.

${ }^{15}$ Müsli (known to English speakers as Muesli) is the dialect-diminuative of Mus: "pap" or "mash," according to Langenscheidt's dictionary,

\author{
Lebensreformer is both singular and plural. \\ Wandervogel, pl.: Wandervögel, means, literally, a \\ migratory bird, and referred to the hikers' movement. \\ Kneipp is the name of a Lebensreformer discussed \\ below (translator's note). \\ 16 Anni Gamerith, 'The privileged position of \\ farinaceous food in Austria', in Alexander Fenton \\ and Trefor M Owen (eds), Food in perspective: \\ proceedings of the Third International Conference of \\ Ethnological Food Research, Edinburgh, John \\ Donalds, 1981, pp. 83-117; Meyer-Renschhausen, \\ op. cit., note 1 above.
}


(Macrobiotics, or the art of lengthening the human life-span), in which he recommended a simple lifestyle and nutrition as the precondition for health, was enthusiastically received. ${ }^{17}$ Politically, too, the movement was anything but reactionary; these early Lebensreformer saw their goal as giving people back some of the power of decision which the rationalization of their environment was in the process of confiscating for good.

Their world-view was based on holistic and vitalistic concepts, with the whole human being as the centre of the diagnosis, not individual symptoms of illness or components of the diet, such as proteins or carbohydrates. ${ }^{18}$ The basic theories were those developed by the Hippocratic School in ancient Greece during the fifth century BC, and still espoused to some extent by alternative practitioners today.

According to the theory of humoral pathology, upon which much of medical practice up to the nineteenth century had been based until Rudolf Virchow's cell pathology revolutionized medical thinking, ${ }^{19}$ the key to health was a finely tuned balance of the four bodily fluids: blood, phlegm, and yellow and black bile, while a poor mixture of these was the result of a wrong way of living, which thus opened the door to illness. Illness was an expression of physiological and psychological disharmonies, and a symptom of the body's struggle to restore a healthy balance. Therapies included fasting, sweating, increasing the quantity of urine through herbal teas, exercise, bloodletting, various bath therapies, and enemas; overdoses and harmful side-effects were to be avoided. In the area of nutrition, whole-grain bread, raw vegetables and fruits were the key elements. ${ }^{20}$ These theories implied that the physically and nutritionally right way of life was also morally the right way- "a sound mind in a healthy body".

In the 1820s, the German farmer Vincenz Prießnitz (1799-1851) began practising the "gentle therapy" of water cures in the Silesian town of Gräfenberg, ${ }^{21}$ which rapidly gained many adherents. The American Presbyterian minister Sylvester Graham (1794-1851) saw the transatlantic cholera epidemic of 1832 as a pathology of "western civilisation" and pleaded for a return to home-baked whole-wheat bread. ${ }^{22}$ The wagonner Johannes Schroth (1798-1856) discovered the hunger and fasting cures named after him, designed to purge the body and purify it of the poisons of luxury consumption. Prießnitz' water-cure methods were further developed during the 1890 s by the clergyman Sebastian Kneipp (1821-1897), achieving instant widespread acclaim. This was one of the key factors

17 Christoph Wilhelm Hufeland, Makrobiotik oder die Kunst, das menschliche Leben zu verlängern, 1796, reissued, Frankfurt am Main, Insel, 1984.

18 Cf. Wolfgang E Krabbe, 'Naturheilbewegung', in Diethart Kerbs, Jürgen Reulecke (eds), Handbuch der deutschen Reformbewegungen, 1880-1993, Wuppertal, Peter Hammer, 1998, pp. 77-85.

19 Rudolf Virchow, Die Cellularpathologie-in ihrer Begründung auf physiologische und pathologische Gewebelehre, Berlin, August Hirschwald, 1858; see also Heinrich Schipperges, Rudolf Virchow, Reinbek bei Hamburg, Rowohlt, 1994, as well as Albert Wirz, Die Moral auf dem Teller, Zurich, Chronos, 1993, p. 156.

${ }^{20}$ Karl E Rothschuh, Konzepte der Medizin in Vergangenheit and Gegenwart, Stuttgart, Hippokrates, 1978.
21 Brauchle, op. cit., note 13 above, p. 60. In 1831 Prießnitz received a state licence to operate a watercure establishment and in 1837 a general licence for a spa. See such contemporary magazines as Allgemeine Wasserzeitung and Der Wasserfreund, both Erlangen.

22 Wirz, op. cit., note 19 above, p. 152; Giedion, op. cit., note 1 above; Richard H Shryock, 'Sylvester Graham and the Popular Health Movement, 1830-1870', Mississippi Valley Historical Review, 1931, 18: 172-83; Robin Price, 'Hydropathy in England 1840-70', Med. Hist., 1981, 25: 269-80; Stephen Nissenbaum, Sex, diet, and debility in Jacksonian America: Sylvester Graham and health reform, Westport, Conn., Greenwood Press, 1980. 


\section{Elisabeth Meyer-Renschhausen and Albert Wirz}

which made natural health so generally popular by the late nineteenth century that it is appropriate to speak of a true mass movement for natural health, which attracted members from all strata of society, including the workering class. ${ }^{23}$

\section{Vegetarianism and Abstentionism}

Within this mass movement, the strict-vegetarians emerged as a definable, radical tendency around the turn of the century, basing their theories on Pythagorean teachings (after the ancient Greek sect named after the philosopher Pythagoras), which had advocated ethical vegetarianism and rejected animal sacrifice. ${ }^{24}$ This tendency appeared throughout the Lebensreform spectrum. Whereas religious or even merely hygienic concepts had predominated during the first half of the century-the groups formed in Britain in 1847 had been founded by dissident Protestant church members-by the late nineteenth century in Germany and Switzerland (probably to a greater degree than in the USA or Britain) Lebensreform became a kind of secular religion with firm ethical principles-more precisely, a kind of secularized protestantism. ${ }^{25}$ Many supporters were probably primarily motivated by considerations of their own health, with hygiene becoming a kind of secular purification: purity instead of religion was the basis for the social order.

An early advocate of this trend was the independent Protestant preacher Eduard Baltzer (1814-1887), who marshalled hygienic, ethical and economic arguments against meateating. Only a society which refrained from eating meat could, he argued, bring about lasting peace, since a diet of animal flesh increased the propensity to aggression. He attributed the origins of both militarism and "unrestrained domination by sexual urges" to overindulgence in meat, citing ideas presented by writers such as the medieval mystic Hildegard of Bingen among others. ${ }^{26}$ Thus, when Max Bircher-Benner started his career, he did so at a time of heated debate within the mass movement for vegetarianism and natural healing.

These more "fundamentalist" strict-vegetarian groups were less numerous than the adherents of the broad Lebensreform spectrum in general; their agenda included not only self-determined, natural healing and a healthy lifestyle, but also questions of ethics and social issues. During the 1880 s, German vegetarianism experienced a wave of settlerutopianism; many emigrated in small groups to North and South America to found communal self-sustaining settlements. ${ }^{27}$ On 28 May 1893, eighteen Berlin vegetarians founded a vegetarian garden colony in nearby Oranienburg; by 1924, it encompassed 440 acres, 200 households and some 700 inhabitants. Although the requirement in the statutes

23 Stollberg, op. cit., note 10 above, pp. 267-86.

24 Maria Dustmann, Die Geschichte der Ernährungstherapie im Altertum, Quakenbrück, Dissertationsdruckerei von Rob. Kleinert, 1935, p.

21; Karl E Rothschuh, Naturheitbewegung,

Reformbewegung, Alternativbewegung, Stuttgart,

Hippokrates, 1983.

25 Anneke van Otterloo, 'Die Bewegung für natürliche und gesunde Nahrung als 'Petite

Religion', Österreichische Zeitschrift für Soziologie,
1993, 18 (4): 41-52; Sebastian Kneipp, So sollt ihr leben, Wörrishofen, author, 1889.

26 See Claudia Huerkamp, 'Medizinische Lebensreform im späten 19. JahrhundertNaturheilbewegung in Deutschland als Protest gegen die naturwissenschaftliche Universitätsmedizin', in Vierteljahreshefte für Sozial- und

Wirtschaftsgeschichte, 1986, 73 (4): 158ff.

27 Ulrich Linse, "Von "Nueva Germania" nach

“Eden”', in Die Bauwelt, 1992, 83: 2453-5. 
of the community for a "vegetarian lifestyle" had in 1903 been replaced by the term "lifereformist lifestyle", most members still continued to abstain from meat. ${ }^{28}$

The roots of this tendency go back to the beginning of the Lebensreform movement in general. In 1843, the journalist Wilhelm Zimmermann (1807-1878), an activist of the 1848 revolution, published his book Der Weg zum Paradies: Eine Beleuchtung der Hauptursachen des physisch-moralischen Verfalls der Culturvölker (The path to paradise: an enlightenment of the main causes of physical and moral degeneration among civilized peoples) in which he preached the return to a natural way of life as a way to a better society. Around 1850, the physician Theodor Hahn (1824-1883) and others praised vegetarianism, which they extolled as a natural therapy.

At Easter 1867, Baltzer, who had been greatly influenced by Hahn, founded the Deutscher Verein für natürliche Lebensweise (Association for Natural Living), in Nordhausen, Thuringia; it was later renamed the Deutscher Verein für naturgemäße Lebensweise (German Association for Living according to Nature). His magazine, the Vereinsblatt für Freunde naturgemäßer Lebensweise, was later retitled Vegetarier. A year later, the association had 106 members. In 1869, Baltzer's old parliamentary colleague from the 1848 revolutionary assembly in Frankfurt's St Paul's Church, the writer Gustav Struve (1805-1870), founded the Vegetarische Gesellschaft Stuttgart, which exists to this day. Struve had published a vegetarian essay as early as 1833 ; in 1869 , he financed the publication of his book Die Pflanzenkost: Grundlagen einer neuen Weltanschauung (A vegetarian diet: the basis of a new Weltanschauung).

Various natural-health magazines were founded during and after the Revolution of 1848 , often surviving only a few years, and then later resurrected under new names. ${ }^{29}$ In 1872 the first natural health association was founded in Saxony; in 1883 it expanded nationally and was renamed the Deutscher Verein für Naturheilkunde und volksverständliche Gesundheitspflege (German Association for Natural Healing and Popularly Comprehensible Health Care). Finally, in 1888, a federation of all the natural-health associations in the country was created under the name Deutscher Bund für Gesundheitspflege und arzneilose Heilweise (German League for Health Care and Healing without Medication). It produced the magazine Naturarzt; and in certain years, a Naturarzt-Kalender appeared. In 1897, this directory listed some 58,000 members of natural-health associations in more than 450 towns throughout the German Empire; the chapter presidents came from all strata of society, while the 301 lecturers were for the most part teachers and merchants. ${ }^{30}$

The membership increased steadily until the beginning of World War I, and by 1913 the natural-health associations organized in the Deutscher Bund had a total of 148,000 members. The previous year, the 25 vegetarian associations in the German Empire had some 5000 registered members. ${ }^{31}$ By 1913 , the anti-alcohol movement, too, had grown,

\footnotetext{
28 Judith Baumgartner, ErnährungsreformAntwort auf Industrialisierung und Ernährungswandel-Ernährungsreform als Teil der Lebensreformbewegung . . . am Beispiel Edens, Frankfurt am Main and Berlin, Peter Lang, 1992.

29 Cf. Journal für naturgemäße Gesundheitspflege und Heilkunde, which appeared in Berlin in 1855; see also Barlösius, op. cit., note 11 above, pp. 289-90.
}

\footnotetext{
30 Cf. Naturarzt-Kalender für 1897, ed. v. Adolf Damaschke, Berlin, Wilhelm Moeller. The directory of the chapters of the Deutscher Bund, pp. 81-90, lists $\mathbf{4 7 5}$ associations with $\mathbf{5 8 , 9 7 0}$ members, in addition to a directory of 301 lecturers from a wide variety of professions. pp. 91-6.

31 Judith Baumgartner, 'Vegetarismus', in Kerbs and Reulecke (eds), op. cit., note 18 above, pp. 127-39.
} 


\section{Elisabeth Meyer-Renschhausen and Albert Wirz}

and here, it was the radicals who had the greatest success. The Deutsche Guttempler- the forerunners of Alcoholics Anonymous - could boast 59,000 members, while the moderate "temperance" organization Verein gegen den Mißbrauch geistiger Getränke had only $24,000 .{ }^{32}$

That the vegetarians' influence on society, during the period shortly before and after World War I, was much greater than these figures indicate can be seen from Berlin address books, which list numerous vegetarian restaurants. ${ }^{33}$ And although Germany's vegetarian movement was strong, there were others that equalled it. In 1889, the International Vegetarian Society was founded and constituted as the international umbrella organization of the world's vegetarians. The movement continued unabated after World War I. The Eighth International Vegetarian Congress was held from 9 to 16 July 1932 with more than 500 delegates at the vegetarian colony in Oranienburg, which by then went under the name Obstbaukolonie Eden (Eden Orchard Colony), and thus reached its zenith. ${ }^{34}$

While the members of the more "radical" vegetarianist movement were for the most part intellectuals from the larger cities, those of the more widespread natural-health associations included many people from the traditional middle classes in the smaller provincial towns: some 30 per cent of the members were craftsmen, 25 per cent were workers, while merchants and government officials each made up around 15 per cent (1908-1912 figures). ${ }^{35}$ Members of the more conservative educated classes tended to gravitate to the so-called Hygienevereine (hygienic associations), loyal to the imperial regime, such as the physician-dominated Deutsche Verein für öffentliche Gesundheit (German Association for Public Health). This has led to the charge that the "bourgeois" Hygienevereine were merely a sinister form of social control or, as Ute Frevert puts it, a "fürsorgliche Belagerung"- a caring siege-attack against the lower classes by the elite. ${ }^{36}$ In fact, as the use of the term Hygienekalender for the registers of the Naturheilvereine indicates, there was no such clear distinction between "progressive" plebeian naturalhealth associations on the one hand and a patrician Hygienebewegung doing the bidding of the Prussian repressive apparatus on the other. ${ }^{37}$ To some extent, the difference was functional-the hygienic associations were, for instance, concerned with the building of modern sewage systems. At the philosophical level, however, the entire movement must be seen as a forerunner of our ecological movement today, with both honest reformers and reactionaries present throughout the spectrum. ${ }^{38}$

The divisions which did exist within the movement, particularly that caused by the emergence of a vegetarian/abstentionist wing as described above-were philosophical and increasingly political, but only to a limited degree socially definable. The radical holism

\footnotetext{
32 James S Roberts, Drink, temperance and the working class in nineteenth century Germany, Boston and London, Allen and Unwin, 1984; MeyerRenschhausen, op. cit., note 2 above, pp. 190-269. The Christian Women's Temperance organization alone had some 150,000 members in the United States in 1895: Ruth Bordin, Woman and temperance: the quest for power and liberty 1873-1900, Philadelphia, Temple University Press, 1981.

33 Senatsbibliothek, Adreßbücher von Berlin (1920-1933: . . . Großberlin) (Berlin Senate Library).
}

\footnotetext{
34 See Eden-Monatsschrift mit Bildern, Aug.-Sept. 1932, 27: 169-210, and Baumgartner, op. cit., note 28 above.

35 Stollberg, op. cit., note 10 above, pp. 267-86, 294 and 289.

36 Ute Frevert, Fürsorgliche BelagerungKrankheit als politisches Problem 1770-1880, Göttingen, Vandenhoek, 1884, 220ff.

37 Cf. Barlösius, op. cit., note 11 above.

38 Cf. Alfons Fischer, 'Öffentliche Hygiene', in Handwörterbuch der Staatswissenschaften, 4th ed., Jena, G Fischer, 1923, pp. 295-317.
} 
of the vegetarians was part and parcel of an emerging socially radical lay tendency which outflanked the medical experts who were drawn in by this popular movement. At the Ninth International Anti-Alcohol Congress in 1903, for instance, abstentionist workers' associations joined with the representatives of the "bourgeois" women's movement, such as the Deutscher Frauenbund für Alkoholfreie Kultur (German Women's League for a Non-Alcoholic Culture) to push through successfully the abstentionist position against that of the more moderate "temperance" forces, such as the Verein gegen den Mißbrauch geistiger Getränke (Association against the Abuse of Spirits); these moderates included physicians who advocated the consumption of beer as a way of reducing the abuse of Schnapps. ${ }^{39}$

Whatever their motives, they were, in the eyes of their opponents, doing the devil'si.e., the brewers'-work, for the main target of the abstentionists and women's rights advocates was the "mandatory drinking" rule in the franchise pubs of Germany's "alcohol-capitalists": the franchising breweries had forbidden the innkeepers to serve even a plate of soup without a tankard of beer. This abstentionist tendency must be seen as merely another aspect of the same radical wing of the Lebensreformer, with many individuals engaged in both areas.

\section{The Movement brings forth "Charismatic Leaders"}

Although the membership figures in the natural health associations reached their peak around 1913, the high point of the movement came at the turn of the century, when lay practitioners and physicians such as Kneipp, Lahmann, Kellogg, Bircher-Benner and others emerged as the charismatic heroes of natural health and vegetarianism. These pioneers of healthy living have left us not only such treatments as Kneipp's cold-water methods, but also such well-known pillars of good nutrition as Bircher-Müsli, Graham or Lieken whole-grain breads and Kellogg's cornflakes, which were created in the late nineteenth or early twentieth century and rapidly became famous. ${ }^{40}$ The level of general recognition of these men was such that their teachings have been passed on down the generations, and through other "oral traditions" as well, so that they constitute a lasting counter-culture of body-awareness.

Although the fragmentary evidence, the poor sources and the bias of written history have led many who sympathize with the ideas of pioneers like Bircher-Benner to imagine them as lonely heroes in the darkest of times, the history outlined above shows that the situation was in fact quite different. In fact, their work is unimaginable without the "mass movement" around them, and they would never have acquired the esteem they did without the selfless help of the Lebensreformer, many of whom were women, including the pioneers' wives, sisters, nieces, etc. Mrs Kellogg, for example, founded a school of home economics and published articles about the rational management of housework. Her writings were thus part of the discourse of the first wave of feminism, in which women

\footnotetext{
39 See Franziskus Hähnel (ed.), Bericht über den IX. Internationalen Kongre $\beta$ gegen den Alkohol abgehalten in Bremen 19. April 1903, Jena, author, 1904; see also Meyer-Renschhausen, op. cit., note 2 above, p. $236 \mathrm{ff}$.
}

\footnotetext{
40 Wolfgang R Krabbe, Gesellschaftsveränderung durch Lebensreform-Strukturmerkmale einer sozialreformerischen Bewegung im Deutschland der Industrialisierungsperiode, Göttingen, Vandenhoek \& Ruprecht, 1974, p. 53.
} 


\section{Elisabeth Meyer-Renschhausen and Albert Wirz}

fought for the rehabilitation of housework and argued that it should be recognized as real work. ${ }^{41}$ But the "movers of women's liberation" should also be seen as part of this feminist wave, particularly the sisters Catherine and Harriet Beecher Stowe who were active in the home economics movement. They warned American women of the late nineteenth century against adopting British aristocratic habits of eating, since they felt, like Hippocrates, that too much beef led to melancholy and mental illness. They also strongly attacked the much-too-sweet puddings in American cookbooks, and the general tendency to gluttony, which turned women into slaves of the hearth. ${ }^{42}$ In Germany, too, such early feminists as Luise Otto-Peters and Lina Morgenstern launched strong attacks against aristocratic dining customs in the middle classes. ${ }^{43}$

The radical-moderate conflict broke out in the United States as well, between an older and a younger generation of vegetarians within the Seventh-Day Adventist Church, who had founded the soon-to-be famous natural health sanatorium in Battle Creek, Michigan. Representing the latter group was the physician the Adventists had hired for the institution, John Harvey Kellogg (1852-1943). The Church elders broke with him in 1903, when they realized that he had turned their religious beliefs into a secular doctrine, promoting the cult of the body in a manner reminiscent of Nietzsche, who saw this as the religion of the twentieth century. ${ }^{44}$ Kellogg may also have stressed hygiene and cleanliness to the detriment of spiritual purity, for, as a surgeon and admirer of Louis Pasteur, he knew about the dangers of bacteria. ${ }^{45}$ Yet he and his younger followers never abandoned the Adventists' ideas of a simple life and a conservative Utopia, and kept to their ideas about purity and health, which were rooted in a concept of moral physiology not unlike that of the Ancients. They, too, were preoccupied with balance and harmony, order and unity, interpreting sickness as a sign of physiological, spiritual, and social or moral imbalances.

As late as the 1890s, German Social Democrats, imbued with the rationalism that gave rise to the term "scientific socialism", tended to sympathize most with the established scientific schools of medicine. None the less, the Lebensreform movements were in close contact with the other social movements of the day, and there was a clear "natural sisterhood" between working-class movements and natural-health associations, such as

41 Ella E Kellogg, Science in the kitchen: a scientific treatise on food substances and their dietetic properties, together with a practical explanation of the principles of healthful cookery, 3rd ed., Battle Creek, Health Publishing Co., 1898. Thanks to women like her, at the turn of the century the international women's movement was successful in establishing a school for domestic science and professionalized housekeeping.

${ }^{42}$ Levenstein, op. cit., note 4 above, pp. 6 and 14.

43 Luise Otto-Peters, Frauenleben im deutschen Reich, Erinnerungen aus der Vergangenheit, Leipzig, Schaeler, 1876. Home-economics-related material in the context of the initial women's movement included: Catherine Beecher, Miss Beecher's domestic recipe book, New York, Harper \& Brothers, 1846; Lina Morgenstern, ErnährungslehreGrundlage zu einer häuslichen Gesundheitspflege, Berlin, Schall und Rentel, 1876 (in response to a food scandal that year), 5th ed., Berlin, 1903; Hedwig Heyl, ABC der Küche, Berlin, Habel,1888; Fannie Farmer, The Boston cooking-school book, Boston, Little, Brown \& Co., 1888; Lehrbuch für eine Lehrerinnenanstalt; Ankennung des Berufs einer staatlich geprüften Hauswirtschafterin, 1908.

44 Cf. Wirz, op. cit., note 19 above, p. 167; Michel Onfray, Der Bauch des Philosophen. Kritik der diätetischen Vernunft, Frankfurt am Main, Campus, 1990, passim.

45 Louis Pasteur is seen as the discoverer of the microbial origin of illness. Through his research on the fermentation of alcohol after 1854, an antiseptic procedure for storing alcohol and milk was developed, which opened up the possibility of keeping beer in bottles ("Lagerbier") and carefully heated milk for several days-new "drinks" for the fast-growing nineteenth-century cities with badly nourished working-class populations. 
the alliance between women's movements and groups against alcohol abuse among workers. These points of common interest led to a dovetailing of the two movements around the turn of the century, a process symbolized by the action of the socialist publichealth advocate and physician August Forel (1848-1931), who gave up his professorship in Zurich in 1897 to have more time for work in the anti-alcohol movement. By 1903, "esoteric" and natural-health lectures were an unquestioned part of the curriculum in Rosa Luxemburg's Party School in Berlin. ${ }^{46}$

With the growth of the Lebensreform movement during the first decade of the new century, the Social Democrats came to accept it. In 1910, SPD Reichstag Deputy Stuicklen defended patients' right to the practitioner of their choice under the national health insurance system, which ensured access to lay practitioners and so-called physiotherapists on an equal basis with academically trained doctors. ${ }^{47}$

In 1928, the communist physician and writer Friedrich Wolf (1888-1953), who wrote the play Cyankali (Cyanide) against repressive anti-abortion laws, published a book on natural health in which he referred to the tradition of humoral pathology. ${ }^{48}$ Most of the socalled physiotherapists shared with the utopian socialists, and others who upheld the essentially pre-capitalist notion of a moral economy with its communitarian values, the idea that we live in a finite world where the profits of the few are gained at the expense of the many. It therefore followed that self-interest was a destructive impulse to be kept in check, either through individual moderation and self-control, or through an elaborate network of reciprocal social controls. The ancient Greek philosophers advocated the same values when they preached sophrosyne (temperance, moderation) as one of the cardinal virtues of civilized life. ${ }^{49}$

This is an aspect which has not yet been given the attention it deserves in the history of medicine, because established scholars tend to misinterpret the quest for harmony and purity within alternative medicine as an expression of simple, irrational backwardness, while many socially-critical thinkers see it as a manifestation of a "repressive" bourgeois society. We propose an alternative interpretation, stressing the affinities between medical and social thinking, between the idea of a just, moral economy and that of the Lebensreformer's moral physiology, with each nourishing the other.

The world-view based on the forces of nature and its cyclical changes, with its model of a hierarchical society rooted in values of moderation and harmonious living, had lost much of its explanatory power in the nineteenth century. It had been called into question by the dramatic rise of capitalism in the nineteenth-century West, when rapid economic growth, urbanization and industrialization created new opportunities and new wealth. The "revolution at the table" 50 described at the outset, with its differing kinds of malnourishment for the poor and the rich, reflected a new wealth of production which also

\footnotetext{
46 See, for example, Harald Szeemann (ed.), Monte Verità, Zürich, Electa Editrice, 1978.

47 In opposition to a Conservative bill against "quackery," designed to ban lay treatment. Cf. Stenographische Berichte aus dem Reichstag, 1912, 262: 3278-324.

48 Friedrich Wolf, Die Natur als Arzt and Helfer-Das neue naturärztliche Hausbuch, Stuttgart, Berlin and Leipzig, Deutsche
}

\author{
Verlagsanstalt, 1928, pp. 29; see also Cornelie \\ Usborne, The politics of the body in Weimar \\ Germany: women's reproductive rights and duties, \\ London, Macmillan, 1992, pp. 163-4; Atina \\ Grossmann, Reforming sex: the German movement \\ for birth control and abortion reform, 1920-1950, \\ New York, Oxford University Press, 1995, pp. 83-5. \\ 49 See Rothschuh, op. cit., note 20 above. \\ 50 Levenstein, op. cit., note 4 above.
}




\section{Elisabeth Meyer-Renschhausen and Albert Wirz}

created mass poverty on an unprecedented scale. Starvation amidst wealth has been the "paradox of plenty" 51 of modern times, as in the 1930s in the United States.

In addition to the "new" opposition movement-socialism-which these developments engendered, there was also opposition from those elements of traditional morality which had survived, and which now revived, gaining the status of a counter-ideology. This was especially true for those marginalized by society-women, members of the underclass and the dispossessed, and even those in the middle classes or from elite backgrounds who, for whatever reason, feared a change for the worse in society, felt lost in the turmoil of social transformation, or were simply dissatisfied with the explanations given by modern medicine for their ailments from which they continued to suffer, despite the promises of the age of reason and linear progress. One of those who shared this tendency to idealize the pre-modern rural past and to equate industrialization and liberal society with conflict, ill-health and decline, if not degeneration, was Maximilian Bircher-Benner.

\section{Maximilian Bircher-Benner}

Maximilian Bircher-Benner (22 August 1867 to 24 January 1939), the "father of Müsli", and perhaps Switzerland's most important contributor to the post-modern lifestyle, was some fifteen years younger than his well-known American colleague John Harvey Kellogg. ${ }^{52}$ In 1897, he ordered a medicinal bath developed by Kellogg, and later sent his eldest son to Battle Creek for an internship. Bircher, who added his wife's maiden name Benner to his own after his marriage in 1899, was the son of a notary public in the Swiss town of Aarau. When he was in his mid-teens, financial disaster hit the family because his father had guaranteed a bad bond. In spite of this sudden poverty, the talented young man was able to read medicine at the nearby University of Zurich, which in the late nineteenth century was a hotbed of new and controversial ideas. He did not like the teaching at the university, which, for all its intellectual brilliance, seemed technical and fragmented, and divorced from real life.

But the lectures of August Forel were different. Forel, an entomologist turned psychiatrist, who was in charge of the local mental hospital, taught Bircher the art of hypnosis. He was also active in the movement against the rampant consumption of alcohol at the university, where drinking was part of the initiation rituals of students. Bircher admired his teacher's courage; clearly, he was the epitome of an independent mind. A firm believer in science and progress, he coupled socialist and pacifist ideas with support for women's liberation, birth control and the fight against prostitution. On the other hand, he also became one of the first practitioners of eugenic sterilization..$^{53}$

Maximilian Bircher-Benner started his career as a general practitioner in a workingclass district of Zurich, which at that time was undergoing a process of rapid industrialization. He gained first-hand knowledge of the problems of the poor, but wanted

51 Levenstein, op. cit., note 8 above.

52 Wirz, op. cit., note 19 above, p. 9; Maximilian Oskar Bircher-Benner, Eine neue Ernährungslehre, Zurich, Wendepunkt, 1924; idem, Vom Wesen und der Organisation der Nahrungsenergie, Zurich, Wendepunkt, 1936; idem, Vom Werden des neuen Arztes, Dresden, Heyne, 1938.
53 See August Forel, Die sexuelle Frage: eine naturwissenschaftliche, psychologische und hygienische Studie nebst Lösungsversuchen wichtiger sozialer Aufgaben der Zukunft, Munich, Ernst Reinhardt, 1920. 
more than that. Not satisfied with what he had learnt at the university, he travelled to Berlin to study the water-cure methods of Sebastian Kneipp, and to Vienna where Wilhelm Winternitz was lecturing on hydrotherapy at the university. On his way he also visited Heinrich Lahmann's fashionable clinic near Dresden, famous for its dietetic therapy. ${ }^{54}$ As a student, Bircher had already used Vincenz Prießnitz' cold body compresses to fight insomnia; now, a German vegetarian student advised the young doctor, with good effect, to administer raw food to a woman suffering from a form of gastritis.

Back from his travels, Bircher closed his medical practice and opened a small centre for physical- and hydrotherapy, and a clinic with seven beds for alternative medicine in an affluent residential part of Zurich. The latter proved such a success that soon he had to relocate and expand. In 1904 he moved the clinic, which he called Lebendige Kraft (vital force), further up the hill, next to the woods on the outskirts of the town, and close to the Dolder Grand Hotel. This was a good move, for he could now socialize with the wealthy and famous guests at the hotel-Russian aristocrats, German and Dutch business people, and famous international artists-precisely those at whom he had originally aimed his medical ideas, as did Kellogg. These people had money, and they suffered from all the ailments and degenerative diseases that he believed were associated with economic growth, affluence, and overeating.

\section{Max Bircher-Benner's Diet}

Like other natural-health practitioners, Max Bircher-Benner abstained as far as possible from the use of drugs, favouring different kinds of natural therapeutic methods such as hydro- and electrotherapy. Like his contemporaries in the life-reform movement, he stressed the healing power of sunlight, fresh air, regular exercises and positive thinking. Each morning, before breakfast, he sent his patients on a long walk in the nearby forest. Like Kneipp, he urged them to get enough sleep and to live a well-ordered life in harmony with nature's cycles, eating moderately, abstaining from stimulants, and avoiding stress. It all added up to a comprehensive regimen that Bircher-Benner called the "Nine Laws of Order", which set out his vision of nature as a living macrocosm, with humankind at its centre. $^{55}$

\footnotetext{
54 See Wirz, op. cit., note 19 above, p. 51. The magazine published by the vegetarian Heinrich Lahmann carried discussions of dress reform from the 1889s on; the 3rd ed. of Heinrich Lahmann's Reform der Kleidung (Dress reform) appeared in 1898. In the vegetarian movement too, the question of clothing always appeared alongside discussions of eating habits from the 1830 on. Wool or cotton was the great point of dispute between followers of Gustav Jaeger and Heinrich Lahmann. See Karen Ellwanger, Elisabeth Meyer-Renschhausen, 'Kleiderreform', in Kerbs and Reulecke (eds), op. cit., note 31 above, pp. 87-102; Brigitte Stamm, 'Das Reformkleid in Deutschland', Diss. Techn. Univ.
}

Berlin 1976; Susanne Kühl, 'Durch Gesundheit zur Schönheit-Reformversuche in der Frauenkleidung um 1900', in Christel Köhle-Hezinger, et al. (eds), Der neuen Welt ein neuer Rock-Studien zu Kleidung, Körper and Mode an Beispielen aus Baden-Württemberg, Stuttgart, Theiß, 1993, pp. 102-11.

55 'Wie werde ich gesund?', in Ralph Bircher, Leben and Lebenswerk Bircher-BennerBahnbrecher der Ernährungslehre und Heilkunde, Zurich, Bircher-Benner, 1959, p. 10; Max BircherBenner, Ordnungsgesetze des Lebens als Wegweiser zur Gesundheit (lst ed. 1938), Zurich, 1977, pp. 9-33. 


\section{Elisabeth Meyer-Renschhausen and Albert Wirz}

The core of Bircher-Benner's therapeutic programme was his dietary plan, which promoted raw food and carbohydrates over cooked food and animal protein, i.e. greens and vegetables rather than bread and meat. He called this a revolutionary diet, and that it was, because, first, it turned prevalent bourgeois culinary values upside down, and second, it contradicted the medical thinking of the day, which stressed the value of animal protein above all else.

Not surprisingly, the medical establishment reacted with horror, when Bircher-Benner first presented his ideas in 1900 to the local medical association. But although his dietetic notions were treated as heresy and quackery by his colleagues, he stood firm, claiming that his ideas were based on the latest discoveries in natural science, particularly the second law of thermodynamics, which stipulates an energy loss with each transformation. ${ }^{56}$

Bircher-Benner reasoned that anything eaten raw had a higher energy and therefore nutritive value than anything cooked, and that with each further process, the value decreased even more. Essential for his argument was the fact that plants can transform energy (sunlight) directly into carbohydrates. He later singled out green leaves as the "key to the whole mystery of nutrition and nutritive value"-a fact which every schoolchild today learns in the first biology lesson-and he called fruit "sunlight food"; to both, he attributed the power to stimulate and strengthen the body's inherent healing power. ${ }^{57}$ Like his contemporaries in the life-reform, natural healing and temperance movements, he spoke out against canned and industrially processed foods, including white flour, polished rice and refined sugar. He also condemned coffee, tea, chocolate and other "stimulants" in the most unambiguous terms.

Without aligning himself with the vegetarians, Bircher-Benner did his best to fight the religion of red meat so prevalent at the time. A talented polemicist, he attacked meat as being like soot-caked coal in a furnace belching fumes-a dirty and inefficient energy source. ${ }^{58}$ Meat had been held in especially high regard since Justus von Liebig, Carl Voit and Max Pettenkofer established the basic principles of metabolism and devised methods of nutritional accounting which seemed to prove that it was the most efficient source of energy and therefore necessary for the working man and all those who lived active lives. Although the scientific basis of these ideas has long been disproved, even today conventional nutritionists uphold them, taking refuge in vague formulations to rescue the still-formidable meat culture. ${ }^{59}$

\footnotetext{
56 Max Bircher-Benner, 'Erste Mitteilung über eine neue Ernährungslehre', in Correspondenz-Blatt für Schweizer Ärzte 30/12, 1900, p. 382; see also Max Bircher-Benner, Vom Wesen and von der Organisation der Nahrungsenergie und über die Anwendung des zweiten Hauptsatzes der Energielehre auf den Nährwert und die Nahrungswirkung, Stuttgart, Hippokrates, 1936.

57 Max Bircher-Benner, 'Die vollwertige Ernährung des Menschen', in SchweizerischeZeitschrift für Hygiene und Archiv für Wohlfahrtspflege, 1930, 10 (1): 791-807.
}

\footnotetext{
58 Max Bircher-Benner, Fragen des Lebens und der Gesundheit, Zurich, Wendepunkt, 1937, p. 37.

59 Cf. Karl Huth, Ernährung und Diätetik, Heidelberg, Quelle \& Meyer, 1979, pp. 16-34. The Gießen University professor Dr Claus Leitzmann told me at a workshop at the 100th anniversary celebration of Eden in 1994 that he had recently, after a struggle, become a "vegetarian". His wife had become one ten years earlier, on the basis of his research (EM-R).
} 


\section{Dietetics, Health Reform and Social Order}

\section{Manly Meat and Womanish Vegetables}

But, of course, meat consumption had other aspects as well. The roast on the dinner table was first and foremost a sign of status and wealth, and in a wider sense it pointed to man's conquest of nature and the wild. It was not surprising, then, that eminent scientists like the zoologist Ernst Haeckel, Darwin's most prolific advocate in Germany, claimed a direct link between meat consumption and health, brain development, liberty, and cultural development. ${ }^{60}$ This reasoning, extravagant as it may seem, fitted in very well with nineteenth-century thinking about gender and food. Jean-Jacques Rousseau, in his pedagogical novel Émile, had developed a clearly gendered view of food. While he assigned meat and spirits to his male hero, Émile, his sweet-natured and obedient future wife, Sophie, was said to have a predilection for cereals, milk and sweets, but "much less so for meat". And she never touched wine or spirits. As Rousseau explained: she stuck strictly to the taste "peculiar to her sex." Moreover, she ate very little. ${ }^{61}$

To be sure, this equation of femininity and masculinity, respectively, with different types of food was never developed into any kind of programme nor even strictly adhered to in everyday routine. But it influenced the behaviour and thinking of many in the nineteenth-century West. The ideal of the bourgeois woman who, if properly socialized, eats little and delicately while man, the hunter and meat eater, indulges in food and drink, spurred the imagination of many writers. In Gerhart Hauptmann's Vor Sonnenaufgang (Before sunrise), a shocking play about sudden wealth and moral decay in a Silesian coalmining district, the only really positive character is a woman, Helene, who conforms to the stereotype just mentioned. The play, which dramatizes the anxiety about degeneration that haunted many in the late nineteenth century, was read and discussed by Bircher and his wife.

Circumstantial evidence such as memoirs and women's life stories also point to the fact that women in the nineteenth century did indeed eat less meat than their men, if only because meat and sausages were among the more expensive food items in Europe. In certain segments of society, this kept women, but not men, on a vegetarian diet. Women, Virginia Woolf wrote, have only enough money for a piece of cake in a café when they travel; and her contemporary, the Bremen author Tami Oelfken, born around 1890, recalled that her teacher, due to her minuscule salary, was only rarely able to purchase very thin pieces of meat at the butcher's. ${ }^{62}$

This gendered perspective on food had a long tradition with roots in the physiology of the Greeks and the Romans, yet it gained new relevance in the nineteenth century. On the one hand, the polarization of gender reached new levels in bourgeois society. On the other, there was a steady increase in the consumption of meat together with economic growth in all industrialized countries. In Germany, for instance, per capita meat consumption per year jumped from $22.0 \mathrm{~kg}$ in 1850 to $44.94 \mathrm{~kg}$ in $1913 .{ }^{63}$ Pork consumption even trebled

\footnotetext{
60 See Ernst Haeckel, Generelle Morphologie der Organismen, Berlin, G Reimer, 1866, vol. 2, p. 235.

61 Jean-Jacques Rousseau, Émile, ou de l'éducation, 1762, see vol. 4 of, Oeuvres complètes, ed. Bernard Gagnebin and Marcel Raymond, Paris, Gallimard, 1969.
}

\footnotetext{
62 Virginia Woolf, A room of one's own, London, Hogarth Press, 1929; Tami Oelfken, Maddo Clüver, Diusseldorf, Progress-Verlag, 1956 (written in 1940, publication banned by the Nazis).

${ }^{63}$ Meat consumption in West Germany reached $70 \mathrm{~kg}$ per capita in 1988 - the peak year.
} 


\section{Elisabeth Meyer-Renschhausen and Albert Wirz}

during the same period. ${ }^{64}$ Moreover, from the 1830 s onwards, these habits received the blessing of the medical profession, who elevated them to the status of a scientific paradigm. Meat and progress, then, seemed to go hand in hand.

We believe that these wider social and cultural connotations have to be kept in mind when considering vegetarianism, gauging its appeal to certain groups within society and assessing the difficulties encountered by those who advocated a meatless diet. Or to put it more bluntly: when Bircher-Benner and Kellogg spoke out against meat, when they praised cereals, vegetables, fruits and greens, they not only challenged the scientific community, but also, at least implicitly, questioned some core values of bourgeois culture. It is thus understandable that those attacked countered with ridicule, as they still do today.

When reformers like Baltzer, Kellogg or Bircher-Benner stressed feminine values in their diets, or more precisely, stressed values which were considered feminine in their societies, they did so only implicitly. They were not in fact feminists at all, although feminist writers were among the first to take up their ideas. Still, Bircher-Benner was fond of quoting the Taoist saying that the weak will prevail, and he admired Gandhi. ${ }^{65}$ When recommending a caloric intake level, Kellogg opted for the standard which the physiologists had set for women. ${ }^{66}$

\section{Vegetarianism as a Critique of Turn-of-the-Century Food Culture}

In his own dietary habits Bircher-Benner was very circumspect. He waited until 1927, when he was almost sixty, before he made public his personal abstention from meat, and then he, too, gave ethical reasons which were in line with the traditional arguments of the Pythagoreans. Before that, he not only refrained from any kind of normative statement regarding meat consumption but, what is even more significant, he tried to fight the scientists on their own ground, claiming that their view of meat as a source of concentrated energy focused exclusively on the first law of thermodynamics, while his recognition of the vegetable basis of the food chain took the second law into account as well. Also, he avidly quoted any and all findings of contemporary science which he thought might vindicate his ideas, while hardly ever acknowledging his debt to other health reformers. He obviously longed to be recognized as a scientist among scientists, while dreading comparison with the many "quacks" who crowded the field of alternative medicine.

Bircher-Benner's ideas, as outlined in his Kurze Grundzüge der Ernährungs-Therapie auf Grund der Energie-Spannung der Nahrung (Brief fundamentals of nutritional therapy on the basis of the energetic tension in food) published in Berlin in 1903, were translated into delicious menus by his sisters Alice Bircher and Berta Brupbacher-Bircher who were in charge of the kitchen at the clinic. The menus and the cuisine were later adapted by his daughter Ruth Kunz-Bircher. ${ }^{67}$ These menus put into practice the reformist critique of the

${ }^{64}$ Hans Jürgen Teuteberg, 'Der Verzehr von Nahrungsmitteln in Deutschland pro Kopf und Jahr seit Beginn der Industrialisierung (1850-1970), Versuch einer quantitativen Langzeitanalyse', in Archiv für Sozialgeschichte, 1979, 19: 345-7.

65 Max Bircher-Benner, Der Menschenseele Not, Part 2, Zurich, Wendepunkt, 1933, p. 199, Part I, Zurich, Wendepunkt, 1927, pp.16-17, 249-54.
66 John Harvey Kellogg, Ladies' guide in health and disease, girlhood, maidenhood, wifehood, motherhood, Battle Creek, Modern Medicine Pub. Co., 1902.

67 Alice Bircher, Diätetische Speisezettel und fleischlose Kochrezepte, Berlin, O Salle, 1906; Berta Brupbacher-Bircher, Das Wendepunkt-Kochbuch, (lst ed. 1927) 7th ed., Basel, Wendepunkt, 1930. 


\section{Dietetics, Health Reform and Social Order}

symbolic order of bourgeois cuisine by inverting it. Everyday meals of the rich at the turn of the century started with a plate of steaming soup or broth, followed by the main course, a cooked dish combining meat, cereals or potatoes and vegetables, and possibly some salad as an accompaniment to be eaten more for variety and pleasure than for its nutritive value. As late as 1882, such experts as the Swiss Federal Inspector of Industries, a physician by profession who had read the relevant scholarly literature of the day, classed vegetables and salads as stimulants, whose main value lay in their salt and acid content! A dessert of either fruit or cake or cream concluded the correct meal. ${ }^{68}$

Bircher-Benner's menus, on the other hand, begin with a bowl of fresh fruit or some Müsli. This was followed by a plate of raw vegetables as the main course before a cooked dish was served, which might or might not have been vegetarian. Only the last dish, the dessert, remained unchanged, both in order and in its ingredients. The Müsli in itself combined all the elements of the radical doctor's teachings on nutrition. Not only was it conceived as the main dish for breakfast and dinner, Bircher-Benner claimed that its nutritional content was as close to mother's milk as could be. Furthermore, unlike most of the pre-packaged Müslis sold in supermarkets, or that advocated by the representatives of the current whole grain philosophy, the main ingredients in the original Müsli were not cereals but fresh fruit: 200 grams of apple per helping, with only a tablespoon of well soaked ground oats, some finely grated nuts for protein and fat, the juice of half a lemon and a tablespoon of sweetened condensed milk. ${ }^{69}$ Instead of apples, one might add berries or other fruit; Bircher-Benner chose apples because they kept fresh even in winter and because he had himself experienced their curative power. Again and again, he told the story of how he had overcome jaundice: his fiancée, a chemist's daughter from Alsace, had fed him chopped apples.

The Swiss health reformer knew that the use of industrially processed milk went against the grain of his basic argument. Yet he adopted it for reasons of hygiene. In any case, he was not averse to compromise when it helped him to convey his main point. Thus, he added oats to his Müsli mainly because people thought that they gave more strength than other cereals, which was, as he said, an unfounded belief. ${ }^{70}$ In fact, oats do contain more protein than any other cereal.

The original Müsli was a frugal dish, and intentionally so, because it was meant to be the essential part of any diet at the clinic. He kept the number of different diets as low possible. Accordingly, he called it a "dietetic apple dish", which sounds very therapeutic indeed. Yet, unlike Kellogg's various types of health food, it did not originate in a medical practice or a clinical laboratory, but was inspired by a dish which Bircher-Benner was served by a woman cowherd on a hiking tour in the Swiss Alps, or so he claimed. ${ }^{71}$ Whether true or not, the story fits well with Bircher-Benner's conviction that rural people in pre-industrial times were much healthier than people in the cities, thanks to their frugal and mainly vegetarian diets. Müsli, then, was a reminder of a golden age when men's and

68 Fridolin Schuler, Über die Ernährung der Fabrikbevölkerung und ihre Mängel, Zurich, Herzog's Verlagshaus, 1882, p.1.

69 Max Bircher-Benner and Max Edwin Bircher, Früchtespeisen und Rohgemüse, 10th ed., Zurich, Wendepunkt, 1929, pp. 22-3.

\footnotetext{
70 Ibid., p. 25.

71 Ralph Bircher, 'Wie entstand das BircherMüesli?', in Neue Züricher Zeitung, 12 March 1944; and in a slightly different version: Ruth KunzBircher, Gesund mit Bircher-Benner, 2nd ed., Bern, Hallwag, 1981, pp. 92-3.
} 


\section{Elisabeth Meyer-Renschhausen and Albert Wirz}

women's lives were (presumably) in tune with providential nature, when society had not yet been ripped apart by all sorts of social conflicts, when all was harmony.

The quest for wholeness was another of those basic tenets in Bircher-Benner's thinking which were transferred to the Müsli. He insisted again and again that it was essential to add not only the finely grated apple pulp to the Müsli, but every bit of the apple, including the peel and the core. In the same vein, the raw vegetable platter was meant to be a mixture of chopped leaves and grated roots with their different textures, nutritive properties and colours.

Bircher-Benner's notion of food as a primordial unity not to be tampered with was contrary to the convictions of Kellogg, who did not mind experimenting with and rearranging the different nutritive contents of food, while still calling his inventions "natural". Similarly, he thought of cooking and baking as processes to ease and speed up digestion. Only in the 1920s did he accept raw food as something healthy to be included in the diet. ${ }^{72}$ Bircher-Benner, by contrast, considered cooking at best a necessary evil. Hence, he recommended gentle methods, such as slow cooking over low heat and steaming rather than frying, the wisdom of which has been borne out by later research.

Repudiated in 1900 by his colleagues, Bircher-Benner felt vindicated when, in the 1920 s and 1930s, nutritionists established that the vitamins and minerals discovered in ever greater numbers by chemists were essential for human health, not least the vitamin $\mathrm{C}$ in fresh fruit. The ensuing vitamin revolution, as it might be called, undoubtedly enhanced the authority of the health reformers. In 1927, Bircher-Benner received further satisfaction, when a young colleague honoured his work in a speech before the same local medical association which had accused him of quackery a quarter of a century earlier. ${ }^{73}$ Doctors at the local paediatric hospital also began to use raw food diets as part of their prescriptions. Müsli was adopted in cookbooks as a light and healthy dish in everyday menus. The growth of service industries in the inter-war years with the concomitant rise in the number of women clerical workers, also helped to increase the demand for light meals. Today, Müsli is common in almost every cancer sanatorium.

None the less, Bircher-Benner's disciples, who tried to live up to the standards of his dietetic regimen, were still mocked as "Müslis". ${ }^{74}$ It should to be stressed, too, that the new research on vitamins and minerals contradicted Bircher-Benner's assumptions as often as they supported them. This is not surprising since the research was based on chemical analysis while Bircher-Benner's diet was the result of a classificatory effort, one based, certainly, on physical considerations, but even more on careful observation, clinical practice and the normative values of an essentially moral physiology.

There is another irony as well: Müsli became popular only when its cereal and sugar content was increased. It thereby changed back into a form of cold cereal mixture not unlike the porridge which had been a traditional staple in much of the pre-industrial West.

72 John Harvey Kellogg, The simple life in a nutshell, Battle Creek, n.p., 1908, p. 4; idem, The new dietetics. What to eat and how. A guide to scientific feeding in health disease, Battle Creek, Modern Medicine Pub. Co., 1921, pp. 228-9, 261.

73 Schweizerische Medizinische Wochenschrift, 1927, 53: 1275.
74 Pierre Itor (pseud. for Paul Rothenhäusler), Das Müesli-Buch, das kleine Kult- and Rezeptbuch, Stäfa, Rothenhäusler, 1991, p. 5; Dr H, 'Die zwei Rohköstler', in Schweizerische Ärztezeitung, 1934, 51: 658 . 


\section{Dietetics, Health Reform and Social Order}

Neophobia seems at least as widespread as neophilia in matters of food, making any nutritional reform a difficult task.

Francis Moore Lappé's book, $A$ diet for a small planet,${ }^{75}$ which became a best-seller during the 1970s, called for vegetarian dietary habits on ethical and social grounds. Thus, in the 1990s we have a situation similar to that of a century ago: again, there is the phenomenon of new social movements which are challenging established thinking across a broad range of issues described by the term "ecology". Within this context, once again, alternative nutritionists and health activists are formulating a counter-agenda to the established academic doctrine, with its generous state-financed research budgets. This agenda is, on the one hand, rooted in an older, holistic world-view, and, on the other, is being scientifically underpinned with increasing success, as ecology develops into an academic discipline in its own right.

The so-called "esoteric" doctrines are winning ever more support from parts of the academic community, as is shown by the establishment at the University of Gießen of a department in the new field of "Nutritional Ecology" with Claus Leitzmann and others with origins in conventional medical dietetics and nutritional research, who are confirming the critique raised by "alternative medicine" of the turn of the century, as well as of today's vegetarians. ${ }^{76}$ Max Bircher-Benner's concepts and those of his predecessors, which in 1900 were still regarded as "visionary", constitute a bridge to pre-modern, traditional societies, which were for them a direct point of contact. That bridge is available to today's much more scientifically grounded "alternative medicine", providing a link both to ancient and medieval doctrines and to folk wisdom.

Clearly, many nutrition-based illnesses cannot be treated by established medical forms unless accompanied by a change in diet. Clearly, too, the crisis of the Western health system is, among other things, indirectly a funding crisis caused by mistaken nutrition. The mistake, as it was a century ago, is "too much of a good thing"-of foods which, in the concentrations consumed today, should be viewed more as drugs than as nourishment. These foods are the result of a system that produces solely for the market, not for human beings ("consumers"). The very transition to a vegetarian diet can have a healing effect; as in 1900, today's "vegetarians" and natural-health advocates argue that a vegetarian diet not only helps the individual, but can also help to bring about a more just global social order.

\footnotetext{
75 Frances Moore Lappé, Diet for a small planet, (lst ed. 1971) 20th ed., New York, Ballantine Books, 1991.

${ }^{76}$ Eva-Maria Spitzmüller, Christine Schönhofer-
}

Pflug, Claus Leitzmann, Ernährungsökologie-Essen zwischen Genuß and Verantwortung, Heidelberg, Haug, 1992, pp. 51, 130. 